\title{
Skrining Thalassemia pada remaja di Desa Tanjung Pering Kecamatan Indralaya Ogan Ilir
}

\author{
Dewi Rosariah $\mathrm{Ayu}^{*}$, Dian Puspita Sari \\ Bagian Ilmu Kesehatan Anak, Fakultas Kedokteran, Universitas Sriwijaya, Palembang, Indonesia \\ dewirosariahayu@yahoo.com, dianpuspitasari@ymail.com
}

\begin{abstract}
Abstrak
Indonesia merupakan salah satu negara yang memiliki penduduk pembawa Thalassemia sekitar 3-8\%, bahkan di beberapa daerah mencapai 10\%. Thalassemia sulit dideteksi karena bersifat asimtomatik sehingga peranan skrining sebagai deteksi dini sangat diperlukan. Skrining Thalassemia diperlukan untuk mencegah dan memutus rantai penyakit kelainan darah merah ini. Tujuan pengabdian masyarakat ini untuk meningkatkan kesadaran dan pemahaman awam di Desa Tanjung Pering, khususnya pada siswa-siswi SMAN 1 Indralaya Utara terhadap gejala penyakit Thalasemia dan penanganannya. Sebanyak 51 orang siswa bersedia ikut serta saat penyuluhan dan pemeriksaan laboratorium. Berdasarkan hasil skrining, terdapat 9 orang $(9.6 \%)$ yang dicurigai sebagai pembawa sifat Thalassemia. Deteksi dini Thalassemia sangat penting untuk memutuskan rantai penyakit ini pada keturunan selanjutnya.
\end{abstract}

Kata kunci: Skrining, Thalassemia

\begin{abstract}
Thalassemia screening for adolescents in Tanjung Pering Village, Kecamatan Indralaya Ogan Ilir. Indonesia is a country that has a Thalassemia carrier population of around 3-8\%, even in some areas reaching $10 \%$. Thalassemia is difficult to detect because it is asymptomatic, so the role of screening as early detection is needed. Thalassemia screening is needed to prevent and break the chain of this blood disorder. The purpose of this community service is to increase awareness and understanding the symptoms and management of thalassemia in Tanjung Pering Village, especially the students of SMAN 1 Indralaya Utara. As many as 51 students take part during counseling and laboratory examination. of blood. Based on screening result, 9 of them (17.6\%) were suspected of being carriers of Thalassemia. Early detection of thalassemia is very important to break the chain of this disease in the next generation.
\end{abstract}

Keywords: Screening, Thalassemia

\section{PENDAHULUAN}

Thalasemia adalah penyakit keturunan dengan gejala utama pucat, perut tampak membesar karena pembengkakkan limpa dan hati. Penyakit ini disebabkan oleh adanya kelainan/ perubahan/ mutasi pada gen globin alpha atau gen globin beta sehingga produksi rantai globin tersebut berkurang dan sel darah merah mudah sekali rusak atau umurnya lebih pendek dari sel darah normal (120 hari) ${ }^{1}$. Menurut Riskesdas 2007, 8 provinsi dengan 
prevalensi lebih tinggi dari prevalensi nasional, antara lain Provinsi Aceh $(13,4 \%)$, DKI Jakara (12,3\%), Sumatera Selatan $(5,4 \%)$, Gorontalo (3,1\%), Kepulauan Riau (3\%), Nusa Tenggara Barat (2,6\%), Maluku (1,9\%), dan Papua Barat(2,2\%). ${ }^{2}$

Angka kejadian Thalassemia dapat ditekan dengan melakukan edukasi dan skrining terhadap pembawa gen thalassemia. Skrining thalasemia diperlukan untuk mencegah dan memutus rantai penyakit kelainan darah merah ini. Sekretaris Direktorat Jenderal Pencegahan dan Pengendalian Penyakit Kemenkes Asjikin Iman Hidayat Dachlan mengatakan, skrining bisa dilakukan sejak dini diantaranya saat anak duduk di bangku sekolah menengah pertama (SMP) dan sekolah menengah atas (SMA). Jika pemeriksaan menunjukkan hasil positif pembawa sifat maka perlu dilakukan konseling genetik sebelum pernikahan atau sebelum hamil. ${ }^{1}$

Berdasarkan hal tersebut, dilakukan deteksi dini menggunakan indikator panel sel darah merah yang sederhana pada siswa-siswi SMAN 1 Indralaya Utara di Desa Tanjung Pering Ogan Ilir. Pengabdian masyarakat ini juga telah mendapat persetujuan dari Dinas Pendidikan Provinsi Sumatera Selatan. Kegiatan ini bertujuan untuk meningkatkan kesadaran dan pemahaman awam terhadap gejala penyakit Thalassemia dan penanganannya.

\section{TINJAUAN PUSTAKA}

Thalassemia merupakan penyakit kelainan darah bawaan yang disebabkan olehmenurun atau tidak adanya sintesis rantai globin- $\alpha$ atau $-\beta$. Ketidakseimbangan sintesis rantai globin menyebabkan diproduksinya kompleks hemoglobin yang tidak stabil. Presipitasi dari globin yang tidak berpasangan akan membuat membran eritrosit rusak sehingga eritrosis lisis sebelum waktunya yang menyebabkan anemia hemolitik dan peningkatan produksi eritrosit sebagai kompensasi tubuh. ${ }^{3}$

Pasien Thalassemia datang dengan beragam kondisi klinis. Pada anamnesis, riwayat penyakit keluarga perlu ditanyakan untuk membantu diagnosis karena thalassemia 
merupakan penyait kelainan darah herediter yang diturunkan secara autosomal resesif dari orang tua kepadaanak-anaknya. ${ }^{4}$

Thalassemia diklasifikasikan berdasarkan penilaian klinis dan aspek genetik. Klasifikasi berdasarkan penilaian klinis Thalassemia dapat dibagi menjadi mayor dengan gambaran klinis berat yang bergantung dengan transfusi, minor yang hampir tidak memiliki gejala klinis dan intermedia yang memiliki gambaran klinis tidak seberat bentuk mayor dan kondisi lebih berat dari bentuk minor. Berdasarkan genetik, Thalassemia diklasifikasikan berasarkan gen subunit globin yang terganggu sintesisnya yang dibagi menjadi $-\alpha$ dan $-\beta .^{5}$

Thalassemia dapat didiagnosis dengan menanyakan riwayat penyakit pasien dan keluarga, melakukan evaluasi klinis, melakukan pemeriksaan darah lengkap, dan analisis hemoglobin. ${ }^{6}$ Oleh karena itu, diperlukan skrining awal pada remaja agar dapat mendeteksi dini kemungkinan Thalassemia.

\section{METODE}

Kegiatan pengabdian masyarakat ini diikuti oleh 51 siswa-siswi SMA kelas 10 dan 11 yang belum diketahui menyandang Thalassemia, bersedia mengikuti penyuluhan dan mengembalikan lembar informed consent dari orangtua masing-masing sebagai persetujuan untuk menjalani pemeriksaan laboratorium darah. Sebelum pengambilan sampel darah, peserta diberikan penyuluhan mengenai penyakit thalassemia, lalu peserta mengisi lembar data diri, dilanjutkan pemeriksaan berat badan, tinggi badan, dan tanda-tanda vital (tekanan darah, nadi, frekuensi napas, dan temperatur).

Pada pemeriksaan laboratorium, dilakukan pengambilan darah sebanyak $3 \mathrm{ml}$, dimasukkan kedalam tabung EDTA, dan dilakukan analisis laboratorium oleh Laboratorium Prodia Palembang untuk dilakukan pemeriksaan kadar $\mathrm{Hb}$, jumlah eritrosit, $\mathrm{MCV}, \mathrm{MCH}, \mathrm{MCHC}$, RDW serta perhitungan indeks Mentzer. Indeks Mentzer adalah parameter yang diperoleh dari pembagian nilai MCV dengan jumlah eritrosit. Identifikasi 
Thalassemia diawali dengan melihat status eritrosit peserta dari data pemeriksaan laboratorium berupa kadar $\mathrm{Hb}$, jumlah eritrosit dan $\mathrm{MCV}$. Selanjutnya dilakukan perhitungan indeks Mentzer. Pasien yang dicurigai Thalassemia adalah pasien dengan indeks eritrosit mikrositer yaitu bila didapatkan MCV $<85 \mathrm{fL}$ dan indeks Mentzer $<13$.

\section{HASIL DAN PEMBAHASAN}

Sebanyak 51 siswa-siswi SMA Kelas 10 dan 11 di SMAN 1 Indralaya Utara mengikuti kegiatan pengabdian masyarakat ini, terdiri dari 13 orang laki-laki dan 38 orang perempuan. Hasil pemeriksaan darah (Tabel 1 dan 2) menunjukkan bahwa sebanyak 4 (7.8\%) orang dengan anemia, sebanyak 9 (17.6\%) orang dengan $\mathrm{MCV}<85 \mathrm{fL}$, serta sebanyak 4 (7.8\%) orang dengan RDW abnormal.

Tabel 1. Parameter Skrining Thalassemia

\begin{tabular}{llc}
\hline Karakteritik & $\mathbf{n}$ & $\mathbf{( \% )}$ \\
\hline Hemoglobin & & \\
$\quad$ Anemia $(<12 \mathrm{~g} / \mathrm{dL})$ & 4 & 7.8 \\
$\quad$ Normal $(\geq 12 \mathrm{~g} / \mathrm{Dl})$ & 47 & 92.2 \\
MCV & & \\
$\quad$ Mikrositer $(<85)$ & 9 & 17.6 \\
$\quad$ Normal $(85-95)$ & 37 & 72.5 \\
$\quad$ Makrositer $(>95)$ & 5 & 9.8 \\
Indeks Mentzer & & \\
$\quad<13$ & 0 & 0 \\
$\geq 13$ & 51 & 100 \\
RDW & & 7,8 \\
Abnormal $(>15)$ & 4 & 92.2 \\
$\quad$ Normal $(10-15)$ & 47 &
\end{tabular}

Tabel 2. Status eritrosit peserta

\begin{tabular}{lcc}
\hline \multicolumn{1}{c}{ Parameter } & Rerata \pm SD & Median (min- maks) \\
\hline Hemoglobin $(\mathrm{g} / \mathrm{Dl})$ & $13.63 \pm 1.298$ & $13.6(10.30-17.20)$ \\
MCV $(\mathrm{fL})$ & $88.57 \pm 5.731$ & $89.5(68.90-100.30)$ \\
Eritrosit $(x 106 / \mu \mathrm{L})$ & $4.766 \pm 0.444$ & $4.69(3.84-5.86)$ \\
Indeks Mentzer & $18.804 \pm 2.640$ & $19.010(13.46-25.14)$ \\
\hline
\end{tabular}


Thalassemia merupakan kelainan genetik yang tidak terkait kromosom seks. ${ }^{7,8}$ Dari 51 orang peserta, didapatkan empat orang dengan anemia $(\mathrm{Hb}<12 \mathrm{~g} / \mathrm{dl})$, dua orang dengan normositer sedangkan dua orang lainnya dengan mikrositer yang dicurigai pembawa sifat Thalassemia. Dari 9 orang yang merupakan pembawa sifat thalassemia hanya terdapat dua orang yang memiliki $\mathrm{Hb}$ rendah. Pada umumnya pembawa sifat Thalassemia biasanya tidak bergejala (asimtomatik) sehingga sulit dideteksi. Oleh karena itu, perlu ditingkatkan kesadaran melalui penyuluhan terhadap pentingnya melakukan skrining karena lahirnya penyandang Thalassemia baru yang berasal dari pernikahan pembawa sifat Thalassemia (Thalassemia beta minor) merupakan masalah kesehatan dunia., ${ }^{9,10}$

Terdapat 9 orang (17.6\%) dengan Indeks Eritrosit mikrositer yang dicurigai pembawa sifat Thalassemia. Selanjutnya dilakukan perhitungan indeks Mentzer dimana apabila didapatkan indeks Mentzer $<13$ merupakan pembawa sifat thalassemia. Namun hasil perhitungan menunjukkan semua pasien dengan hasil eritrosit mikrositer tersebut memiliki indeks Mentzer $\geq 13$ sehingga kemungkinannya adalah defisiensi besi. Hal ini sesuai dengan penelitian yang dilakukan oleh Sri Lestari di kota Palembang dimana Indeks Mentzer cut of point 13.51 dengan sensitifitas 93\% dan spesifisitas 84\% dalam mendiagnosis anemia defisiensi besi. ${ }^{11}$ Oleh karena itu, pada siswa tersebut diberikan surat keterangan serta dilakukan konseling dan dianjurkan untuk pemeriksaan lanjutan berupa serum iron, total iron binding capacity, dan feritin untuk menegakkan suatu anemia defisiensi besi.

\section{SIMPULAN}

Pembawa sifat thalassemia bersifat asimtomatik sehingga peran deteksi dini terhadap thalassemia sangatlah penting dalam memutus kelahiran penyandang thalassemia mayor. Kesadaran masyarakat untuk memeriksakan diri, tidak lepas dari kesadaran mereka yang dapat diperoleh melalui edukasi atau penyuluhan. Terdapat 9 orang yang dicurigai sebagai pembawa Thalassemia, yang disarankan untuk menjalani pemeriksaan lebih lanjut untuk menegakkan diagnosisnya. 


\section{Referensi}

1. IDAI. Artikel Mengenal Thalasemia. Diakses Pada Tanggal 15 September 2019 dari http://www.idai.or.id/artikel/seputar-kesehatan-anak/mengenal-thalasemia. Jakarta. 2016

2. Riset Kesehatan Dasar. Jakarta: Badan Penelitian dan Pengembangan Kesehatan, Departemen Kesehatan, Republik Indonesia. 2007.

3. Martin A dan Martin AA. Thalassemia. Pediatric Clin N Am. 2013; 60: 1384-91.

4. Regar J. Aspek Genetik Talasemia. Jurnal Biomedik. 2009;1(3): 151-58.

5. Weatherall DJ dan Clegg JB. The Thalassemia Syndromes. Dalam: Gibbons, R., et al. (Editor). The Thalassemia's Syndromes. 4th Edition. Philadelphia: Elsevier Saunders. 2001.

6. Ghosh K, Colah R, Manglani M, Choudhry VP, Verma I, Madan N, et al. Guidelines for screening, diagnosis and management of Hemoglobinopathies. Indian Journal of Human Genetics. 2014;20(2): 101-19.

7. Grow K, Vanish M, Abrol P, Sharma S, Yadav R. Beta Thalassemia in India: Current Status and the Challenges Ahead. Internasional Journal of Pharmacy and Pharmaceutical Sciences. 2014;6(4): 2833.

8. Langlois S, Ford JC, Chitayat D. Carrier Screening for Thalassemia and Hemoglobinophaties in Canada. Joint SOGC-CCMG Clinical Practice Guideline. 2008;218: 950-9

9. Kementrian Kesehatan Republik Indonesia. Health Technology Assesment Indonesia. Pencegahan Thalassemia. 2010. P.6

10. Qazi RA. Screening for Beta Thalassemia trait. Journal of Rawalpindi Medical College. 2014;18(1): 158-60

11. Lestari S, Purnamasari R, Bahar E, Rahadian KY. Mentzer Index as screening tool for iron deficiency anemia in 6-12 year old children. Paediatrica Indonesiana. 2014;5(54): 294-8 